\title{
Differences in responses of moderately salt-tolerant and salt-sensitive tree species to heterogeneous salinity
}

\author{
X.H. FENG ${ }^{1,2 *}$, P. AN ${ }^{3}$, K. GUO ${ }^{1}$, X.G. LI $^{1,2}$, and X.J. LIU ${ }^{1}$ \\ Key Laboratory of Agricultural Water Resources, Center for Agricultural Resources Research, Institute \\ of Genetic and Developmental Biology, Chinese Academy of Sciences, Shijiazhuang, 050023, P.R. China ${ }^{1}$ \\ University of Chinese Academy of Sciences, Beijing 100101, P.R. China ${ }^{2}$ \\ Arid Land Research Center, Tottori University, Tottori 6800001, Japan ${ }^{3}$
}

\begin{abstract}
Growth responses of the moderately salt-tolerant velvet ash (Fraxinus velutina) and salt-sensitive poplar (Populus $\times$ euramericana) were investigated under heterogeneous root zone salinity. The salinity treatments imposed on the two root zones (lower-higher) were 137-137 (uniform), 103-171, 68-205, 34-239, and 0-273 mM NaCl for velvet ash, and 51-51 (uniform), 34-68, 17-85, and 0-103 mM NaCl for poplar. The leaf gas exchange of the plants was measured one month after these treatments were implemented, and the plants were sampled $75 \mathrm{~d}$ after treatment to measure other physiological parameters. Net photosynthetic rate, transpiration rate, total biomass, and fine root compensatory growth increased as the difference in salinity between the two root zones (i.e., salinity heterogeneity) increased in velvet ash. These parameters showed no significant difference among the treatments in poplar. The leaf $\mathrm{Na}^{+}$content was lower under heterogeneous salinity than under uniform salinity in both tested species. The leaf proline content in velvet ash decreased under heterogeneous salinity compared to that under uniform salinity, whereas that of poplar increased. The soluble sugar content of velvet ash leaves increased under heterogeneous salinity, whereas no changes were observed in poplar. The increased fine root biomass in the lower salinity zone promoted velvet ash growth by decreasing the leaf $\mathrm{Na}^{+}$and $\mathrm{Cl}^{-}$content under heterogeneous salinity. The poplar's undifferentiated root distribution and gas exchange in response to the heterogeneous salinity were attributed to its salt sensitivity.
\end{abstract}

Additional key words: Fraxinus velutina, photosynthesis, poplar, Populus $\times$ euramericana, transpiration, velvet ash.

Studies on plant salt tolerance have been widely conducted. Most of these studies were performed under uniform salinity. However, the spatial distribution of salts in the soil is highly variable (Bazihizina et al. 2012a,b). There may be a high variation in salinity even in the rhizosphere of a single plant (Li et al. 2011). Therefore, studies on growth responses to heterogeneous salinity are essential for understanding plant growth under natural saline conditions. Studies on moderately salt-tolerant crops, such as tomato (Mulholland et al. 2002), cotton
(Dong et al. 2010, Kong et al. 2012) and alfalfa (Sun et al. 2016), have shown that plant growth under heterogeneous salinity is more dependent on the lowest rather than on the highest salinity level in the root zone, even when the mean salinity is the same. However, in extremely salt-tolerant or salt-sensitive plants, the responses are different from those of moderately salttolerant plants. The halophyte Atriplex nummularia shows similar growth under uniform and heterogeneous salinity (Bazihizina et al. 2012b). The growth of a salt-

Submitted 31 January 2017, last revision 22 November 2017, accepted 13 December 2017.

Abbreviations: CC - fine root compensation coefficient; $\mathrm{E}$ - transpiration rate; $\mathrm{P}_{\mathrm{N}}$ - net photosynthetic rate; $\mathrm{PVC}$ - polyvinyl chloride; SS - soluble sugar.

Acknowledgements: This study was supported by the National Key Technology R\&D Program of China (2013BAC02B01), the National Key Research and Development Programme of China (2016YFC0501308, 2016YFC0501303), and the China Postdoctoral Science Foundation (2017M620886). This study was also funded by ALRC, Tottori University, Japan (28GR002).

* Corresponding author; e-mail: fxhcaf@163.com 
sensitive species Capsicum annuum with one half of the roots subjected to non-saline conditions depended on the highest salinity around the second root half (Lycoskoufis et al. 2005). Cucumber, which is also a salt-sensitive species, had the same yield under heterogeneous and uniform salinity treatments (Mulholland et al. 2002). These results indicate that the growth responses of different plants to heterogeneous salinity are species specific.

Improvement in the growth of plants under heterogeneous salinity was found to be related to the distribution of roots. More roots in lower-salinity zones improves water absorption by plants (Shani et al. 1993, Bazihizina et al. 2009, Sun et al. 2016). Bazihizina (2009) reported that leaf water potential is negatively correlated with lower salinity in a heterogeneous root zone. The increase in biomass and yield in the heterogeneous salinity treatment compared to that under uniform salinity can be due to increased gas exchange (Dong et al. 2010, Kong et al. 2012) and decreased leaf $\mathrm{Na}^{+}$content (Sun et al. 2016). Heterogeneous salinity leads to lower $\mathrm{Na}^{+}$accumulation in cotton leaves compared to that under uniform salinity (Kong et al. 2012). The backward transportation of $\mathrm{Na}^{+}$from the leaves to the roots occurs when half of the roots experienced non-saline conditions (Kong et al. 2012, Sun et al. 2016). However, little is known about $\mathrm{Cl}^{-}$, proline, and soluble sugar accumulation in plants under heterogeneous salinity, which are important responses of plants to salinity.

Tree species, which have large roots, are expected to be greatly affected by heterogeneous salinity. In addition, previous studies, which have been based on single species, provide no information on growth differences among trees with different salt tolerance. In the present study, we selected two tree species, moderately salt tolerant velvet ash (Fraxinus velutina Torr.; Du et al., 2013), and salt sensitive hybrid poplar (Populus $\times$ euramericana Guinier; Sixto et al. 2005, Chen and Polle 2010) to compare their growth and physiological responses to heterogeneous salinity.

The velvet ash seedlings were grown in tissue culture, and cuttings from young branches of poplar were grown in small pots in a greenhouse. When the height of the plants reached $10-12 \mathrm{~cm}$, they were transplanted into the split-root pots. Polyvinyl chloride (PVC) tubes with an inner diameter of $25 \mathrm{~cm}$ and height of $40 \mathrm{~cm}$ were used. A round PVC board attached to the end of the tube served as the bottom of each pot. A rectangular PVC board $40 \mathrm{~cm}$ long and $25 \mathrm{~cm}$ wide was inserted centrally into each pot to separate the root zone into two equal parts. On top of the board, a $7.5 \times 7.5 \mathrm{~cm}$ hole was cut to place the plant. The crevices of the pot were sealed. Four holes, $1 \mathrm{~cm}$ in diameter, were drilled into the bottom of the pots for drainage. The root zones of the pots were filled with $11 \mathrm{~kg}$ of clean sand with particles $0.05-0.1 \mathrm{~mm}$ in diameter. Each plant was placed centrally into a split-root pot. After trans-plantation, $400 \mathrm{~cm}^{3}$ of a half-strength Hoagland solution (Arnon and Hoagland 1940) was added into each root zone of the pots and then every $4 \mathrm{~d}$. Thirty days later, when the plants were approximately $30 \mathrm{~cm}$ in height and roots had developed in both root zones of the pots, the heterogeneous salinity treatments were implemented. Equal mean salinity treatments were applied based on the salinity at which a $50 \%$ reduction in growth in comparison to $0 \mathrm{mM} \mathrm{NaCl}$ was observed for both tested species. For velvet ash, the mean $\mathrm{NaCl}$ concentration of the two root zones of each pot was set at $137 \mathrm{mM} \mathrm{NaCl}$ (Xu et al. 1994), and this was used in both root zones for the uniform salinity treatment. Four heterogeneous salinity treatments, 103-171, 68-205, 34-239, and 0-273 mM NaCl (lower-higher root zone salinity) were applied. Poplar is much more sensitive to salinity, as low $\mathrm{Na}^{+}$accumulation in leaves can reduce the water content and growth rate (Chen et al. 2002, Janz et al. 2012); therefore, the mean $\mathrm{NaCl}$ concentration of the two root zones was set at $51 \mathrm{mM} \mathrm{NaCl}$ and this concentration was used in both root zones for the uniform salinity treatment. Three heterogeneous salinity treatments, 34-68, 17-85, and 0-103 $\mathrm{mM} \mathrm{NaCl}$, were applied. $\mathrm{NaCl}$ was added to a full-strength Hoagland solution to obtain the desired concentrations. To avoid the accumulation of salt in the pots, an additional $500 \mathrm{~cm}^{3}$ of the treatment solution was irrigated into each root zone of the split-root pots. As a result, the electrical conductivity of the drainage water at the end of each irrigation event was almost the same as that of the irrigation solution. Plastic film was used to prevent evaporation from the pots. There were 6 replicates for each treatment. The salinity treatments lasted $75 \mathrm{~d}$. During the treatments, the day/night temperature range was $14-16 / 22-28{ }^{\circ} \mathrm{C}$, a relative humidity $50-60 \%$, a 12 -h photoperiod, and an irradiance of $600-1000 \mu \mathrm{mol} \mathrm{m} \mathrm{m}^{-2} \mathrm{~s}^{-1}$.

Leaf gas exchange parameters were measured from 09:00 to 11:00 h on two consecutive sunny days after the salinity treatments had been implemented for $30 \mathrm{~d}$ in the uppermost fully expanded leaves using a $L i-6400$ photosynthesis system ( $\mathrm{Li}$-COR, Lincoln, NE, USA). The ambient relative humidity was $50-60 \%$, and the leaf and air temperatures were both $20-25{ }^{\circ} \mathrm{C}$. The rate of air flow and the photosynthetically active radiation were set at $500 \mu \mathrm{mol} \mathrm{s}{ }^{-1}$ and $800 \mu \mathrm{mol} \mathrm{m} \mathrm{s}^{-2}$, respectively. At the end of experiment, shoot height was measured. The leaves and shoots were sampled separately. The roots in each zone of the pots were carefully washed with water and divided into fine roots (diameter $<1 \mathrm{~mm}$ ) and coarse roots (diameter $>1 \mathrm{~mm}$ ). The root stump in the small pot, which did not belong to either of the root zones, was also sampled. The leaf, stem, stump, coarse root, and fine root samples were dried at $85^{\circ} \mathrm{C}$ for $3 \mathrm{~d}$.

The differential root growth between the two root zones was estimated using the compensation coefficient (Mou et al. 1997). The root compensation coefficient is the ratio of the difference between the fine root biomass 
in the lower and higher salinity zones to the total fine root biomass of the whole plant. The leaf soluble sugar and proline content were determined using the methods of Yemm and Willis (1954) and Bates (1973), respectively, with a spectrophotometer (UV-1750, Shimadzu, Kyoto, Japan). The $\mathrm{Na}^{+}$content in the leaves and fine roots was determined using an atomic absorption spectrophotometer (WYC-402C, Shengfen, Shenyang, China) according to $\mathrm{Xu}$ et al. (2011). The $\mathrm{Cl}^{-}$content was determined using the silver nitrate titration method (Lao 1988).

The means and standard deviations (SDs) were calculated, and the measured parameters were compared using the least significant difference test $(L S D)$ in SPSS 16.0. The figure was prepared using SigmaPlot v. 11.0
(Systat Software, Chicago, IL, USA).

Our results show that the shoot height of velvet ash in the $0-273 \mathrm{mM} \mathrm{NaCl}$ treatment was significantly higher than that in all the other treatments except for the 34-239 $\mathrm{mM} \mathrm{NaCl}$ treatment. In poplar, no significant change in plant height was observed among the treatments (Table 1). For the total biomass of velvet ash, the $0-273 \mathrm{mM} \mathrm{NaCl}$ treatment significantly increased the total biomass compared to the other treatments, and the root biomass increased with increasing salinity heterogeneity (Fig. 1A). Poplar showed a slight but nonsignificant increase in total plant and root biomass under some heterogeneous salinity treatments (Fig. 1B).

Table 1. Shoot height, leaf net photosynthetic rate $\left(\mathrm{P}_{\mathrm{N}}\right)$, transpiration rate $(\mathrm{E})$, fine root compensation coefficient $(\mathrm{CC})$, leaf proline content, and soluble sugar (SS) content of velvet ash and poplar treated with 137-137, 103-171, 68-205, 34-239, and 0-273 mM NaCl and 51-51, 34-68, 17-85, and 0-103 mM NaCl (lower-higher) in root zones, respectively. Means \pm SDs, $n=6$. Different letters indicate significant differences among the treatments for the same species $(P<0.05)$. The fine root compensation coefficient is the ratio of the difference between the fine root biomass in the lower and higher salinity zones to the total fine root biomass.

\begin{tabular}{llllllll}
\hline Species & $\begin{array}{l}\mathrm{NaCl} \\
{[\mathrm{mM}]}\end{array}$ & $\begin{array}{l}\text { Shoot height } \\
{[\mathrm{cm}]}\end{array}$ & $\begin{array}{l}\mathrm{P}_{\mathrm{N}} \\
{\left[\mu \mathrm{mol}\left(\mathrm{CO}_{2}\right) \mathrm{m}^{-2} \mathrm{~s}^{-1}\right]}\end{array}$ & $\begin{array}{l}\mathrm{E} \\
{\left[\mathrm{mmol}\left(\mathrm{H}_{2} \mathrm{O}\right) \mathrm{m}^{-2} \mathrm{~s}^{-1}\right]}\end{array}$ & $\begin{array}{l}\mathrm{CC} \\
{\left[\mathrm{mg} \mathrm{g}^{-1}(\mathrm{~d} . \mathrm{m})\right]}\end{array}$ & $\begin{array}{l}\text { Leaf SS } \\
{\left[\mathrm{mg} \mathrm{g}^{-1}(\mathrm{~d} . \mathrm{m})\right]}\end{array}$ \\
\hline Velvet ash & $137-137$ & $68.57 \pm 3.52^{\mathrm{b}}$ & $12.82 \pm 1.60^{\mathrm{c}}$ & $5.43 \pm 1.24^{\mathrm{b}}$ & $-0.03 \pm 0.21^{\mathrm{b}}$ & $7.38 \pm 3.26^{\mathrm{a}}$ & $7.78 \pm 1.41^{\mathrm{b}}$ \\
& $103-171$ & $68.63 \pm 1.72^{\mathrm{b}}$ & $12.58 \pm 1.69^{\mathrm{c}}$ & $5.43 \pm 0.83^{\mathrm{b}}$ & $0.04 \pm 0.25^{\mathrm{b}}$ & $5.85 \pm 2.79^{\mathrm{ab}}$ & $9.70 \pm 1.26^{\mathrm{a}}$ \\
& $68-205$ & $68.43 \pm 1.29^{\mathrm{b}}$ & $13.64 \pm 1.38^{\mathrm{bc}}$ & $5.66 \pm 0.48^{\mathrm{b}}$ & $0.16 \pm 0.25^{\mathrm{ab}}$ & $5.45 \pm 1.56^{\mathrm{b}}$ & $10.11 \pm 1.73^{\mathrm{a}}$ \\
& $34-239$ & $71.25 \pm 2.42^{\mathrm{ab}}$ & $14.46 \pm 1.30^{\mathrm{ab}}$ & $6.42 \pm 0.20^{\mathrm{a}}$ & $0.44 \pm 0.38^{\mathrm{a}}$ & $4.19 \pm 2.22^{\mathrm{b}}$ & $10.24 \pm 0.99^{\mathrm{a}}$ \\
& $0-273$ & $73.88 \pm 1.38^{\mathrm{a}}$ & $15.61 \pm 1.25^{\mathrm{a}}$ & $6.71 \pm 0.45^{\mathrm{a}}$ & $0.52 \pm 0.21^{\mathrm{a}}$ & $3.12 \pm 1.71^{\mathrm{b}}$ & $9.76 \pm 1.24^{\mathrm{a}}$ \\
& $51-51$ & $90.33 \pm 10.17^{\mathrm{a}}$ & $10.98 \pm 2.99^{\mathrm{a}}$ & $4.39 \pm 1.62^{\mathrm{a}}$ & $0.01 \pm 0.17^{\mathrm{a}}$ & $2.06 \pm 1.17^{\mathrm{b}}$ & $7.65 \pm 2.22^{\mathrm{a}}$ \\
& $17-85$ & $93.00 \pm 11.54^{\mathrm{a}}$ & $10.97 \pm 1.70^{\mathrm{a}}$ & $5.74 \pm 0.61^{\mathrm{a}}$ & $0.02 \pm 0.10^{\mathrm{a}}$ & $6.82 \pm 1.65^{\mathrm{a}}$ & $8.10 \pm 0.71^{\mathrm{a}}$ \\
& $34-68$ & $93.67 \pm 6.95^{\mathrm{a}}$ & $12.07 \pm 3.09 \mathrm{a}$ & $6.44 \pm 2.02^{\mathrm{a}}$ & $0.10 \pm 0.08^{\mathrm{a}}$ & $7.71 \pm 1.53^{\mathrm{a}}$ & $7.44 \pm 1.16^{\mathrm{a}}$ \\
& $0-103$ & $90.33 \pm 6.53^{\mathrm{a}}$ & $11.71 \pm 1.70^{\mathrm{a}}$ & $6.42 \pm 1.66^{\mathrm{a}}$ & $-0.01 \pm 0.26^{\mathrm{a}}$ & $5.54 \pm 2.45^{\mathrm{a}}$ & $6.50 \pm 1.82^{\mathrm{a}}$ \\
\hline
\end{tabular}

The fine root biomass of velvet ash increased with decreasing $\mathrm{NaCl}$ concentration in both salinity zones of the heterogeneous salinity treatment (Fig. 1C). The fine root biomass in the zone with $0 \mathrm{mM} \mathrm{NaCl}$ was significantly higher than that in the other treatments, being almost three-fold that in the $273 \mathrm{mM}$ zone. The difference in fine root biomass between the lower and higher salinity zones correlated with the compensation coefficient of the fine roots, which increased with an increase in salinity heterogeneity. In velvet ash, the compensation coefficients of the fine roots increased with an increasing difference in salinity between the two zones (Table 1). For poplar, the fine root biomass in each root zone and the total fine root biomass showed no significant difference among the treatments (Fig. 1D). The fine root compensation coefficients of poplar were close to zero and showed no significant difference among the four treatments (Table 1).

The net photosynthetic rate $\left(\mathrm{P}_{\mathrm{N}}\right)$ of velvet ash generally increased with an increasing difference in salinity between the two root zones (i.e., increasing salinity heterogeneity). The photosynthetic and transpiration (E) rates in the 0-273 and 34-239 $\mathrm{mM} \mathrm{NaCl}$ treatments were significantly higher than those in the 137-137 and 103-171 mM treatments. In poplar, there was no significant difference among the treatments in terms of $\mathrm{P}_{\mathrm{N}}$ or $\mathrm{E}$ (Table 1$)$.

In velvet ash, the leaf proline content decreased with increasing salinity heterogeneity (Table 1). In the heterogeneous salinity treatments, it was lower than that in the uniform salinity treatment. The leaf soluble sugar content was significantly higher in the heterogeneous salinity treatments than in the uniform salinity treatment. The leaf proline content in poplar, in contrast to that in velvet ash, increased significantly in the heterogeneous salinity treatments (Table 1). No significant difference in the soluble sugar content of poplar was found among the treatments.

The $\mathrm{Na}^{+}$content in velvet ash leaves and fine roots decreased with an increase in salinity heterogeneity (Fig. 1E). The $\mathrm{Na}^{+}$content in leaves was significantly lower than that in fine roots. The root $\mathrm{Na}^{+}$content in the lower salinity zones was lower than that in the higher salinity zones for each heterogeneous salinity treatment. The $\mathrm{Cl}^{-}$content in leaves and fine roots also decreased with increasing salinity heterogeneity and was much 


\section{X.H. FENG et al.}

higher in the leaves than in the fine roots (Fig. 1G). The $\mathrm{Cl}^{-}$content of fine roots in the lower salinity zones was lower than that in the higher salinity zones in all the heterogeneous salinity treatments. In poplar, the leaf $\mathrm{Na}^{+}$ content in the heterogeneous salinity treatments was significantly lower than that in the uniform salinity treatment (Fig. 1F). The $\mathrm{Na}^{+}$content in fine roots in the lower salinity zones was lower than that in the higher salinity zones in each of the heterogeneous salinity treatments. The $\mathrm{Na}^{+}$content in leaves was significantly lower than that in fine roots in all treatments. The $\mathrm{Cl}^{-}$ content in leaves was significantly higher than that in fine roots in all the treatments. The $\mathrm{Cl}^{-}$content in leaves in the heterogeneous salinity treatments was slightly lower than that in the uniform salinity treatment (Fig. 1H). No difference in $\mathrm{Cl}^{-}$content in the fine roots was observed

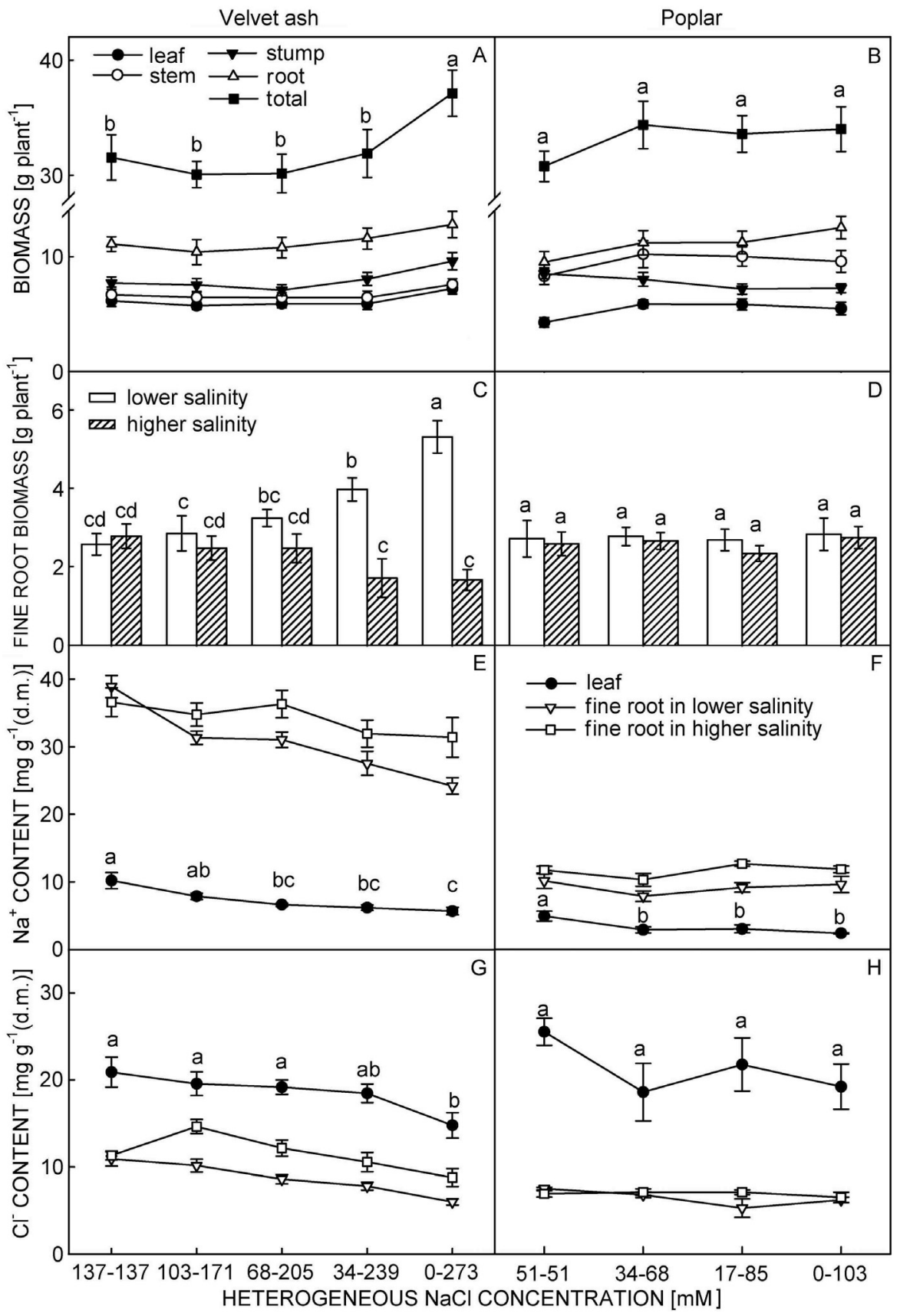

Fig. 1. Leaf, stem, stump, root, and total biomass $(A$ and $B)$, fine root biomass in lower and higher salinity zones $(C$ and $D)$, content of $\mathrm{Na}^{+}(E$ and $F)$ and $\mathrm{Cl}^{-}(G$ and $H)$ in the leaves and fine roots of velvet ash and poplar treated with 137-137, 103-171, 68-205, 34-239, and 0-273 $\mathrm{mM} \mathrm{NaCl}$ and 51-51, 34-68, 17-85, and 0-103 $\mathrm{mM} \mathrm{NaCl}$, respectively. Means \pm SEs, $n=6$. Different letters indicate significant differences among the treatments for the same species $(P<0.05)$. 
among the treatments. In velvet ash, the significant increase in growth under the $0-273 \mathrm{mM} \mathrm{NaCl}$ treatment may have resulted from decreased leaf $\mathrm{Na}^{+}$and $\mathrm{Cl}^{-}$ content and increased photosynthesis.

The lower proline content and higher soluble sugar content of leaves under heterogeneous salinity than under uniform salinity implies the existence of effective mechanisms for osmotic adjustment under saline conditions because the synthesis of soluble sugar is more energy-efficient than the synthesis of proline, and lower energy consumption is likely to promote plant growth under saline stress (An et al. 2005). The absorption of nutrients, water, and salts as well as the exclusion of salts are processes that occur mainly in the fine roots (Rewald et al. 2011). In velvet ash, the growth response to the series of heterogeneous salinity treatments might be largely attributed to the increase in total fine root biomass, which in turn depended mainly on the growth of fine roots in the lower salinity zone. The increase in the root compensation coefficient implies that velvet ash has the ability to adjust the distribution of its roots under heterogeneous salinity. The altered root distribution in response to the root environment might be related to hormonal adjustment of the roots in different salinity zones (Kong et al. 2016). Meanwhile, the average fine root diameter should decrease with increased salinity, and the change in root structure may affect ion absorption and so salt resistance. The growth, ion accumulation, and root distribution of velvet ash under heterogeneous salinity were consistent with previous reports on moderately salttolerant species (Mulholland et al. 2002, Dong et al. 2010, Kong et al. 2012, Sun et al. 2016).

In poplar, the slight increase in growth under heterogeneous salinity might be related to decreased $\mathrm{Na}^{+}$ and $\mathrm{Cl}^{-}$content (Chen et al. 2009), which might have alleviated salinity stress. However, growth was not significantly promoted under heterogeneous salinity, indicating the presence of other metabolic processes that had offset these advantages. The significant increase in proline content under heterogeneous salinity might be one of the factors that caused the greater consumption of photosynthates and energy. The relatively efficient process of osmotic adjustment, i.e., the synthesis of soluble sugar rather than proline, did not appear to be active in poplar under heterogeneous salinity. The similar fine root growth in the two root zones differing in salinity indicated that this plant had no ability to adjust the distribution of roots in environments with heterogeneous salinity. The gas exchange, ion accumulation, and root distribution of poplar under heterogeneous salinity were consistent with previous reports on salt-sensitive species (Mulholland et al. 2002, Lycoskoufis et al. 2005).

Velvet ash actively responded to heterogeneous salinity, which was evident from the change in gas exchange, fine root growth, and soluble sugar synthesis. In contrast, the responses of poplar were not as evident, except for the increase in transpiration rate and proline content. The differences between the two species in response to heterogeneous salinity might be attributed to the differences in the patterns of fine root growth under heterogeneous salinity and the leaf $\mathrm{Na}^{+}$and $\mathrm{Cl}^{-}$accumulation. Velvet ash is moderately salt tolerant ( $\mathrm{Xu}$ et al. 1994, Du et al. 2013), and it is likely that indole acetic acid signalling in the roots triggers the differential growth of fine roots under heterogeneous salinity (Kong et al. 2016). Further, this species limited the transport of $\mathrm{Na}^{+}$ and $\mathrm{Cl}^{-}$from the roots to the leaves (Wang et al. 2009) and underwent osmotic adjustments (Zeng et al. 2015). Poplar is much more sensitive to salinity than velvet ash (Chen and Polle 2010) but did not produce more roots in the lower salinity zone under heterogeneous salinity. Uder salinity, it transported $\mathrm{Na}^{+}$and $\mathrm{Cl}^{-}$to the leaves, which was the main cause of the reduction in plant growth. The difference in $\mathrm{Na}^{+}$and $\mathrm{Cl}^{-}$accumulation in leaves may depend on the absorption of these ions by the fine roots. For poplar, the uniform ion content in the fine roots and root distribution under heterogeneous salinity led to undifferentiated leaf $\mathrm{Na}^{+}$and $\mathrm{Cl}^{-}$accumulation. However, the decreased $\mathrm{Na}^{+}$and $\mathrm{Cl}^{-}$content in the fine roots and the production of fewer fine roots in the higher salinity zone in velvet ash prevented the $\mathrm{Na}^{+}$and $\mathrm{Cl}^{-}$ accumulation in the leaves above a toxic level.

In future studies, the interactions among soluble sugar and proline synthesis, salt accumulation, root distribution, root structure, and other related mechanisms of the response to uniform and heterogeneous root zone salinity need to be further investigated.

207, 1973.

Bazihizina, N., Barrett-Lennard, E.G., Colmer, T.D.: Plant growth and physiology under heterogeneous salinity. - Plant Soil 354: 1-19, 2012.

Bazihizina, N., Barrett-Lennard, E.G., Colmer, T.D.: Plant responses to heterogeneous salinity: growth of the halophyte Atriplex nummularia is determined by the root-weighted mean salinity of the root zone. - J. exp. Bot. 63: 6347-6358, 2012.

Bazihizina, N., Colmer, T.D., Barrett-Lennard, E.G.: Response 
to non-uniform salinity in the root zone of the halophyte Atriplex nummularia: growth, photosynthesis, water relations and tissue ion concentrations. - Ann. Bot. 104: 737-745, 2009.

Chen, S., Li, J., Fritz, E., Wang, S., Hüttermann, A.: Sodium and chloride distribution in roots and transport in three poplar genotypes under increasing $\mathrm{NaCl}$ stress. - Forest Ecol. Manage. 168: 217-230, 2002.

Chen, S.L., Polle, A.: Salinity tolerance of Populus. - Plant Biol. 12: 317-333, 2010.

Chen, W., Zou, D., Guo, W., Xu, H., Shi, D., Yang, C.: Effects of salt stress on growth, photosynthesis and solute accumulation in three poplar cultivars. - Photosynthetica 47: 415-421, 2009.

Dong, H., Kong, X., Luo, Z., Li, W., Xin, C.: Unequal salt distribution in the root zone increases growth and yield of cotton. - Eur. J. Agron. 33: 285-292, 2010.

Du, Z., Wang, Q., Xing, S., Liu, F., Ma, B., Ma, H., Liu, D.: Fine root distribution, characteristics and rhizosphere soil properties in a mixed stand of Robinia pseudoacacia and Fraxinus velutina in a saline soil. - Silva fennica 47, 2013.

Janz, D., Lautner, S., Wildhagen, H., Behnke, K., Schnitzler, J., Rennenberg, H., Fromm, J., Polle, A.: Salt stress induces the formation of a novel type of 'pressure wood' in two Populus species. - New Phytol. 194: 129-141, 2012.

Kong, X., Luo, Z., Dong, H., Eneji, A.E., Li, W.: Effects of non-uniform root zone salinity on water use, $\mathrm{Na}^{+}$ recirculation, and $\mathrm{Na}^{+}$and $\mathrm{H}^{+}$flux in cotton. - J. exp. Bot. 63: 2105-2116, 2012.

Kong, X., Luo, Z., Dong, H., Eneji, A.E., Li, W.: $\mathrm{H}_{2} \mathrm{O}_{2}$ and ABA signaling are responsible for the increased $\mathrm{Na}^{+}$efflux and water uptake in Gossypium hirsutum L. roots in the non-saline side under non-uniform root zone salinity. - J. exp. Bot. 67: 2247-2261, 2016.

Lao, J.: Manual of Soil Agrochemical Analysis. - China Agriculture Press, Beijing 1988.

Li, C., Li, Y., Ma, J.: Spatial heterogeneity of soil chemical properties at fine scales induced by Haloxylon ammodendron (Chenopodiaceae) plants in a sandy desert. Ecol. Res. 26: 385-394, 2011.

Lycoskoufis, I.H., Savvas, D., Mavrogianopoulos, G.: Growth, gas exchange, and nutrient status in pepper (Capsicum annuum L.) grown in recirculating nutrient solution as affected by salinity imposed to half of the root system. - Sci. Hort. 106: 147-161, 2005.

Mou, P., Mitchell, R.J., Jones, R.H.: Root distribution of two tree species under a heterogeneous nutrient environment. J. appl. Ecol. 34: 645-656, 1997.

Mulholland, B.J., Fussell, M., Edmondson, R.N., Taylor, A.J., Basham, J., McKee, J., Parsons, N.: The effect of split-root salinity stress on tomato leaf expansion, fruit yield and quality. - J. hort. Sci. Biotechnol. 77: 509-519, 2002.

Rewald, B., Ephrath, J.E., Rachmilevitch, S.: A root is a root is a root? Water uptake rates of Citrus root orders. - Plant Cell Environ. 34: 33-42, 2011.

Shani, U., Waisel, Y., Eshel, A., Xue, S., Ziv, G.: Responses to salinity of grapevine plants with split root systems. - New Phytol. 124: 695-701, 1993.

Sixto, H., Grau, J.M., Alba, N., Alia, R.: Response to sodium chloride in different species and clones of genus Populus L. - Forestry 78: 93-104, 2005.

Sun, J., Yang, G., Zhang, W., Zhang, Y.: Effects of heterogeneous salinity on growth, water uptake, and tissue ion concentrations of alfalfa. - Plant Soil 408: 211-226, 2016.

Wang, Y., Liu, D., Sun, M., Liu, R.: The study on distribution of $\mathrm{Na}^{+}, \mathrm{K}^{+}$and $\mathrm{Cl}^{-}$in different vegetative organs of Fraxinus velutina. - J. Shihezi Univ. (Natur. Sci.) 27: 27-29, 2009.

$\mathrm{Xu}$, G., Tian, B., Qiao, Y.: Effect of $\mathrm{NaCl}$ affecting the seed germination and young tree growth of Fraxinus velutina. Shannxi Forest Sci. Technol.: 9-12, 1994.

Xu, J., Yin, H., Yang, L., Xie, Z., Liu, X.: Differential salt tolerance in seedlings derived from dimorphic seeds of Atriplex centralasiatica: from physiology to molecular analysis. - Planta 233: 859-871, 2011.

Yemm, E.W., Willis, A.J.: The estimation of carbohydrates in plant extracts by anthrone. - Biochem J. 57: 508-514, 1954.

Zeng, F., Li, L., Liang, N., Wang, X., Li, X., Zhan, Y.: Salt tolerance and alterations in cytosine methylation in the interspecific hybrids of Fraxinus velutina and Fraxinus mandshurica. - Euphytica 205: 721-737, 2015. 